\title{
Socio economic status of fishermen in nam pan village tract, inle lake in Myanmar
}

\begin{abstract}
Socio economic status of fishermen in Nam Pan Village tract were indicated based on age, sex, marital status, household size, educational level, fishermen experience and monthly income. Data and information were used interview to fishermen. The majority of fishermen were male at the age of 20-30 years. The household size 4-6 persons and most of them are married. The most of the fishermen in the study area were drop out in primary education. The monthly income from sale of fishes were 16000-20000 kyats per month. The fishermen were not commercial fish farmer because their incomes were sufficient only for subsistence. These adverse effects include water pollution from fertilizer and pesticides application in and around Inle Lake. The present data indicate the lake is affected by human activities and to sustain of some endemic and nearly threatened freshwater fish of the Inle wetland area.
\end{abstract}

Volume 3 Issue 2 - 2018

\author{
Seint Seint Win \\ Kyaingtong University, Myanmar
}

Correspondence: Seint Seint Win, Lecturer, Department of Zoology, Kyaingtong University, Eastern Shan State, Myanmar, Email seintseintwin22@gmail.com

Received: February 17, 2018| Published: April 17, 2018

Keywords: water, Inle Lake, Nam Pan Village, myanmar, fishermen

\section{Introduction}

Fish are among the world's most important natural resources, providing humans with numerous ecosystem goods and services, including an annual harvest of over 100 million tons of wild biomass worldwide. ${ }^{1}$ The fisheries in sector is vitally important for socioeconomic development Myanmar. Both commercial and traditional fishing as well as aquaculture are significant, providing food, income and employment for the local populations. ${ }^{2}$ Inle Lake is a freshwater lake located in Taunggyi district of Southern Shan State and second largest lake in Myanmar. The Lake provides the livelihood for about 460 fisher families and many "floating garden" agriculturists, and service provider such as boatmen. In Nam Pan Village tract, Pauk Par and Kyar Taw villages, both villages are within the Lake and the Intha people live on the lake and make a living by fishing and fish farming. They use several types of fishing gears when fishing. They can fish throughout the year. However, Inle Lake becomes narrower and shallower. The shrinkage is the erosion of soil and deposition of silt into the Lake. Inle Lake is not only a very important wetland of Myanmar but also freshwater hot spot area of the world because it has many endemic species found in Inle Lake. The present study has been undertaken with the following objectives: to operate the community based assessment in the study area.

\section{Materials and methods}

Study area: Inle Lake is located in the Southern Shan State of Myanmar. It lies between $20^{\circ} 36^{\prime} 07^{\prime \prime} \mathrm{N}$ and $96^{\circ} 55^{\prime} 38^{\prime \prime} \mathrm{E}, 900 \mathrm{~m}$ above sea level. Nam Pan Village is located $20^{\circ} 27^{\prime} 58^{\prime \prime} \mathrm{N}, 96^{\circ} 54^{\prime} 38^{\prime \prime} \mathrm{E}$. The present study was conducted from January 2017 to January 2018.

A total of 50 fishermen within the Nam Pan Village Tract were randomly selected and interviewed to collect and analyze the data of their socio-economic status. Of the 50 fishermen, 25 of them were from Pauk Par village and the other 25 were from Kyar Taw village. All data were analyzed by using descriptive statistics. Each indicator was verified by the fishermen (Figure 1-7).

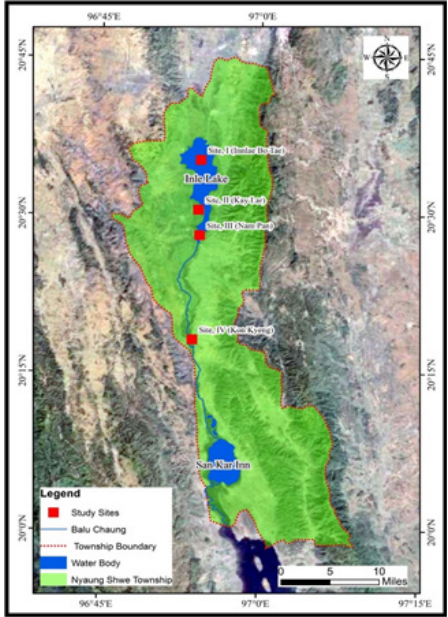

Figure I Map of Inle Lake.

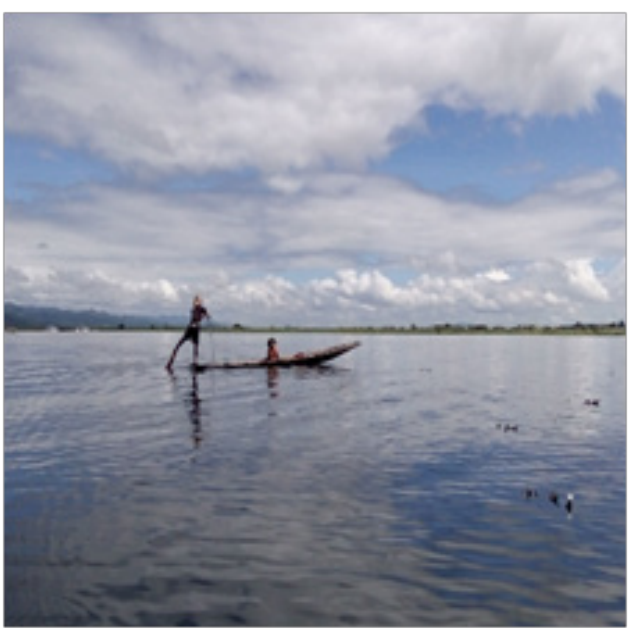

Figure 2 Inle Lake. 


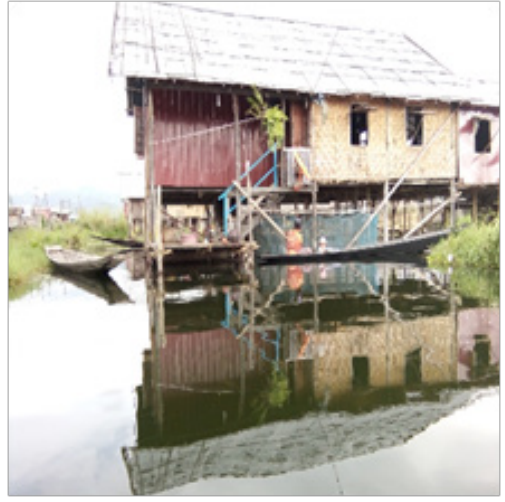

Figure 3 Floating cage under house in Pauk ParVillage.

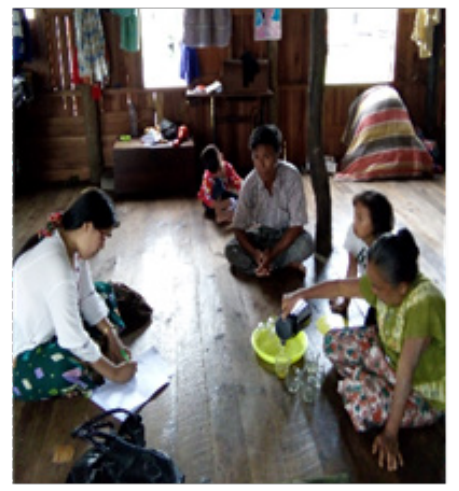

Figure 4 Interview the fisherman in Kyar Taw Village.

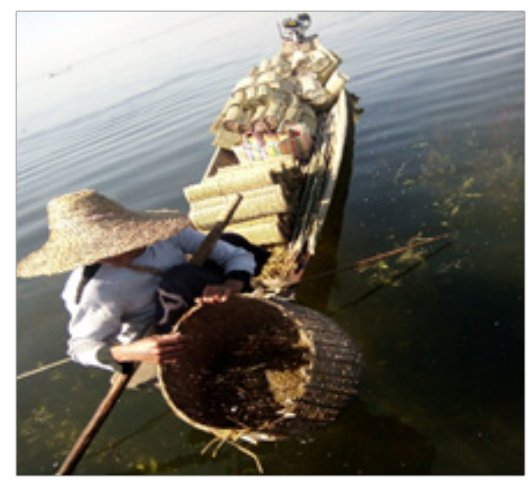

Figure 5 Fisherman set up the traps.

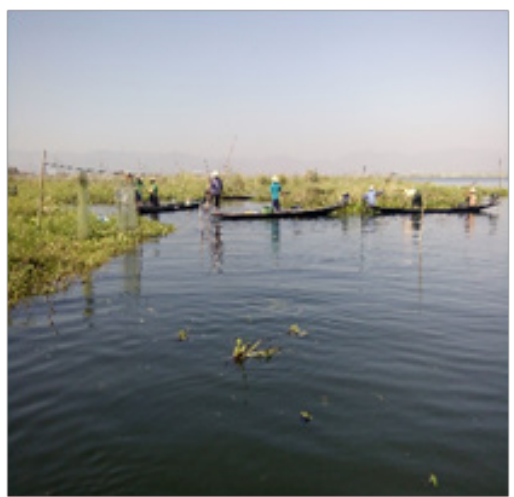

Figure 6 Fishermen set up the gill nets.

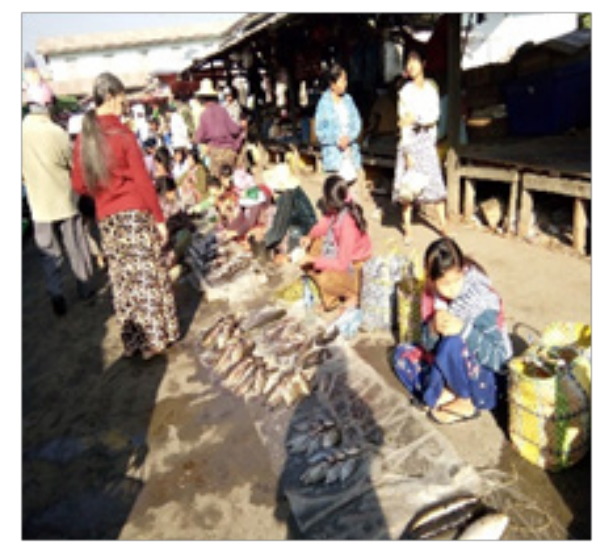

Figure 7 Fish sellers in Nyaung Shwe market.

\section{Result and discussion}

The socio-economic status of fishermen in Nam Pan Village tract (Pauk Par and Kyar Taw village) were collected by directly interview to fishermen (Table 1). The most of the range age of fishermen in study area were 20-30 years and the majority of fishermen was male (92\%). Most of them are married. The age of 20-30 years (38\%) was the most productive fishermen in this study area where men play important role in the development of the fisheries resources of Inle Lake. Silviyunan ${ }^{3}$ reported that the young farmers were productive and innovative and brave to have investment. The most of the respondents' house hold size were 4-6 persons (54\%). It was large family size and educational level were primary school (66 \%) and $34 \%$ were middle school. The result revealed that most of fishermen in study area were poor educated people who could not easily change advanced culture system. Most of the fishing experiences of fishermen in study area were 6-10 years $(40 \%)$ and over 20 years $(22 \%)$. Therefore, most of the fishermen were experience in fishing. According to Radheyshyam et al. ${ }^{4}$ human resources in the development of aquaculture were very important. They stated that in the rural areas the human resources played very important role for the implementation of aquaculture operations.

The number of nets they set 1-20 units/day (44\%) in Inle lake. The most of respondents have 2 units of floating net cages (40\%). The fingerlings were purchased from the private hatchery $84.62 \%$. The majority of fishermen (34.62 \%) cultured African catfish and 26.92\% of fishermen cultured Grass carp and Inle carp. This fishes were the marketable fish in the study area. Therefore, they had funding from the floating net cages. In the study area, the fishermen were not commercial fish farmer because their incomes were sufficient only for subsistence. Most of the respondents' monthly incomes of the fishermen from sales of fishes 40\% were 160000-200000 kyats per month and 30\% earned from 100000-150000 kyats per month. FAO ${ }^{2}$ stated that in Inle Lake, daily catch value was estimated at US\$1425 or US\$519 650/year. The average gross income was US\$25.50/fisher/ month or US\$305.96/fisher/year. The local fishermen said that a lot of introduce fishes were abundant in study area. Thus, indigenous fish species were disturbed by introduce species; especially the productivity of Inle carp was gradually declining. Other factors, such as poor water quality, reducing of the water level, and diseases, were constrained in hot season. The constraints factor reduces fish production and social income of the study areas. Inle Lake needs to 
be managed for water quality and biodiversity. The major problem suggested was eutrophication, and the data indicate the Lake is affected by human activities. The lower DO value indicates that the water quality has been decreasing. The continuing expansion of floating cultivation can be worsening the pollution. The results of this environment can be highlighted to inform the Inle people about the concern in tomato cultivation. They should use the organic fertilizers properly instead of the chemical ones.

\begin{tabular}{|c|c|c|}
\hline Parameters & Frequency & Percentage \\
\hline \multicolumn{3}{|l|}{ Age of Respondents } \\
\hline Less than 19 & 8 & 16 \\
\hline $20-30$ & 19 & 38 \\
\hline $31-40$ & 7 & 14 \\
\hline $4 \mid-50$ & 7 & 14 \\
\hline More than 50 & 9 & 18 \\
\hline Total & 50 & 100 \\
\hline \multicolumn{3}{|l|}{ Sex of Respondents } \\
\hline Male & 46 & 92 \\
\hline Female & 4 & 8 \\
\hline Total & 50 & 100 \\
\hline \multicolumn{3}{|c|}{ Marital status of respondents } \\
\hline Single & 14 & 28 \\
\hline Married & 36 & 72 \\
\hline Widowed & 0 & 0 \\
\hline Total & 50 & 100 \\
\hline \multicolumn{3}{|l|}{ Household size (person) } \\
\hline $1-3$ & 13 & 26 \\
\hline $4-6$ & 27 & 54 \\
\hline $7-10$ & 10 & 20 \\
\hline Total & 50 & 100 \\
\hline \multicolumn{3}{|l|}{ Educational level } \\
\hline Primary & 33 & 66 \\
\hline Middle & 17 & 34 \\
\hline High & 0 & 0 \\
\hline Graduate & 0 & 0 \\
\hline Total & 50 & 100 \\
\hline \multicolumn{3}{|c|}{ Fishermen Experience (Year) } \\
\hline $\mathrm{I}-5$ & 8 & 16 \\
\hline $6-10$ & 20 & 40 \\
\hline $11-15$ & 7 & 14 \\
\hline $16-20$ & 4 & 8 \\
\hline Above 20 & II & 22 \\
\hline Total & 50 & 100 \\
\hline \multicolumn{3}{|c|}{ Number of Gill Nets (Units) } \\
\hline $1-20$ & 22 & 44 \\
\hline $21-40$ & 20 & 40 \\
\hline $4 \mid-60$ & 8 & 16 \\
\hline Above 6I & 0 & 0 \\
\hline Total & 50 & 100 \\
\hline \multicolumn{3}{|c|}{ Number Floating Net Cages /Household (Units) } \\
\hline None & 24 & 48 \\
\hline $\mathrm{I}-2$ & 20 & 40 \\
\hline $3-4$ & 6 & 12 \\
\hline More than 5 & 0 & 0 \\
\hline Total & 50 & 100 \\
\hline \multicolumn{3}{|l|}{ Source of Fingerlings } \\
\hline Private hatchery & 22 & 84.62 \\
\hline Government hatchery & 0 & 0 \\
\hline Personal hatchery & 0 & 0 \\
\hline Wild & 4 & 15.38 \\
\hline Total & 26 & 100 \\
\hline \multicolumn{3}{|l|}{ Culture Species } \\
\hline Common carp+ Grass carp & 4 & 15.38 \\
\hline Grass carp & 2 & 7.69 \\
\hline Grass carp+ Inle Lake carp & 7 & 26.92 \\
\hline Feather back & 4 & 15.38 \\
\hline African catfish & 9 & 34.62 \\
\hline Total & 26 & 100 \\
\hline \multicolumn{3}{|c|}{ Monthly income from sales of fish } \\
\hline $100000-150000$ kyats & 15 & 30 \\
\hline $160000-200000$ kyats & 20 & 40 \\
\hline $210000-250000$ kyats & 4 & 8 \\
\hline $260000-300000$ kyats & 11 & 22 \\
\hline Total & 50 & 100 \\
\hline
\end{tabular}


Department of Fishery (DOF) was annually reminding farmers to participate in the sustainable fishery in Inle Lake. More breeding and rearing of the rare fish species in specific ponds, such as nursery ponds and grow out ponds, should be carried out under the management of the government and the higher education sector in Shan State. The fingerlings of Cyprinus intha and Labeo rohita were released annually by Department of Fishery, Nyaung Shwe. It could be suggested that the release of fingerlings into Inle Lake will be beneficial for both the ecosystem and the livelihoods of the fisherman communities living in Inle Lake. Therefore, the requirement for sustainable development of fishery is performed in the study area. In this way, the native and endemic species will be appraised, and the amount of damage will incline. At the same time, the Inle Lake environs become the reliable areas for the Inle (Intha) people..$^{5-7}$

\section{Acknowledgement}

I would like to profound thanks are due to my supervisor Dr Mie Sein, Pro-rector, Mawlamyine University, for her valuable advice while serving on my research. I am indebted to U Khin Mg Gyi, Professor and Head (Retired), Department of Zoology, Mandalay University of Distance Education, for his understanding and criticisms of the manuscripts.

\section{Conflict of interest}

Author declare that their in no conflict of interest.

\section{References}

1. Hillborn R, Branch TA, Ernst B, et al. State of the world's fisheries. Annual Review of Environment and Resources. 2003;(28):359-399

2. FAO. Fisheries and Aquaculture. National Action Plan for Agriculture (NAPA); 2016. 79 p.

3. Silviyanun. Analysis of floating net cage fish farming in Laut Tawar Lake Aceh Province, Indonesia. Department of Geography Education Faculty of Social sciences, State University of Medan, Indonesia; 2013.

4. Radheyshyam, Saha GS, Safui L, et al. Status and community of fish farming in rural Odisha. Indian Journal Fisheries. 2013;(60):59-67.

5. FAO. Indicators for Sustainable Development of Marine Culture Fisheries Food and Agriculture Organization of the United Nations. Rome; 2017.

6. Hafrijal Syandri, Elfiondri, Ainul Mardiah, et al. Social status of Nile tilapia hatchery fish-farmers at Maninjau lake area, Indonesia. $J$ Fish Aquat Sci. 2016;(11):411-417.

7. Tude AB, Kuton MB, Olahdipo AA, et al. Economic analyze of costs and return of fish farming in Saki-East Local Government Area of Oyo State, Nigeria. J Aquac Res Development. 2015;(5):1-5. 